\title{
Regulatory $T$ cells and innate immune regulation in tumor immunity
}

\author{
R.-F. Wang
}

Published online: 10 August 2006

(C) Springer-Verlag 2006

The online version of the article can be found at http://dx.doi.org/ 10.1007/s00281-006-0022-7

R.-F. Wang $(\bowtie)$

Center for Cell and Gene Therapy, Baylor College of Medicine, ALKEK Building, N1120,

Houston, TX 77030, USA

e-mail: Rongfuw@bcm.tmc.edu

\section{R.-F. Wang}

Department of Pathology, Baylor College of Medicine, ALKEK Building, N1120,

Houston, TX 77030, USA

R.-F. Wang

Department of Immunology, Baylor College of Medicine,

ALKEK Building, N1120,

Houston, TX 77030, USA
Springer Semin Immun (2006) DOI 10.1007/s00281-0060022-7

The author's first address "Cancer Institute, Second Affiliated Hospital, Zhejiang University Medical School, Hangzhou, People's Republic of China" and in the Acknowledgements section "China NSF 30025039" were erroneously published. 